\title{
The big breakthrough of environmental issues in Sweden, autumn 1967
}

In the autumn of 1967, the Swedish environmental debate changed. At that time, a number of prominent scientists publicly warned of an impending global catastrophe. The impact was powerful. There was talk of a general awakening. The press, radio, and television reported on mercury-poisoned fish, biocides, and acid rain. In the apt words of Lars J. Lundgren, it was as if a new continent of problems had been discovered. Previously, various environmental hazards had been regarded as individual islands of problems. Now more and more people were beginning to see them as connected. ${ }^{1}$

At the centre of this development was Hans Palmstierna. That October, he published a debate book in paperback format: Plundring, svält, förgiftning [Plundering, famine, poisoning]. He wanted it to 'awaken and create clarity' about the human situation. Palmstierna argued that there was an urgent need to act 'before the hourglass expired for humanity'. ${ }^{2}$ It was characteristic of Palmstierna that he linked environmental destruction with other global issues, such as world poverty, war, and overpopulation. He emphasized that the Earth was a small sphere with a limited surface area. For that

1 Jan Thelander and Lars J. Lundgren, Nedräkning pågår: Hur upptäcks miljöproblem? Vad händer sedan? (Solna: National Environment Protection Board, 1989); Martin Bennulf, Miljöopinionen i Sverige (Lund: Dialogos, 1994). This chapter is based on David Larsson Heidenblad, 'Mapping a New History of the Ecological Turn: The Circulation of Environmental Knowledge in Sweden 1967', Environment and History 24.2 (2018) and David Larsson Heidenblad, 'Överlevnadsdebattörerna: Hans Palmstierna, Karl-Erik Fichtelius och miljöfrågornas genombrott i 1960-talets Sverige', in Fredrik Norén and Emil Stjernholm (eds), Efterkrigstidens sambällskontakter (Lund: Mediehistoriskt arkiv/Media History Archives, 2019).

2 Hans Palmstierna, Plundring, svält, förgiftning (Stockholm: Rabén \& Sjögren, 1967). Back cover text. 
reason, we must 'stop the population growth if humanity is to survive'. ${ }^{3}$ Palmstierna predicted an apocalyptic time through which humanity must pass 'in order to be healed into common sense and humility in the face of the implacable laws that prevail in all living things'. ${ }^{4}$

Palmstierna's tone of voice was loud and strong but not unique. In the preface to another discussion book published in paperback in the autumn of 1967, Människans villkor: En bok av vetenskapsmän för politiker [The predicament of man: a book by scientists for politicians], Karl-Erik Fichtelius, professor of histology at Uppsala University, wrote that '[d]oomsday prophets have existed for as long as there have been humans. What is new is that now every politically aware scientist can come forward as a doomsday prophet. ${ }^{5}$

Fichtelius was the editor and initiator of Människans villkor. The book assembled twelve major researchers, including the physicist Hannes Alfvén, the economist Gunnar Myrdal, and the food researcher Georg Borgström. Published in December, the book caused an intense debate about the relationship between science and politics. However, one of the participants, Swedish Academy member Lars Gyllensten, had already given a high-profile radio lecture in October. It emphasized that the basic biological conditions for human existence were in the process of being destroyed. Gyllensten said that knowledge about this serious situation was widespread, but that it was not being taken seriously. It would require a 'conscious, effective and unsentimental retraining of us all' if the global problems were to be solved. ${ }^{6}$

Humanity's survival was central to the Swedish environmental debate in the autumn of 1967. At the same time, however, environmental issues were also being discussed in a lower key. The Social Democrat Valfrid Paulsson held a crucial position in this context. In July that year, he had been appointed director-general of the National Environment Protection Board. Most scientific researchers also adopted this more low-key approach. That was noticeable not least in the report by the 1964 government enquiry into natural

3 Palmstierna, Plundring, svält, förgiftning, p. 15.

4 Ibid., p. 9.

5 Karl-Erik Fichtelius, 'Preface' in Karl-Erik Fichtelius (ed.), Människans villkor: En bok av vetenskapsmän för politiker (Stockholm: Wahlström \& Widstrand, 1967), p. 5.

6 'Angeläget', Sveriges Radio, 21 October 1967; Lars Gyllensten, 'Politik och undanflykt', Kvällsposten (KvP), 3 November 1967. 
resources, which was submitted in November 1967. Behind the two-volume report was the country's scientific expertise in the environmental field. The enquiry had surveyed the state of knowledge about, and the extent of, various forms of poisoning and pollution. The perspective was national rather than global. Better planning and more research resources were requested. There was no talk of having to retrain people or of establishing a global government. ${ }^{7}$

Even so, the report did point out that environmental problems were not a strictly national matter. This was especially true of Svante Odén's discovery of acid rain. The emissions occurred on the main European continent, but the rain fell on Sweden. International cooperation was necessary to deal with the problem. It is noteworthy how the realization that there was danger afoot was made public: it was presented in an article on Dagens Nybeter's culture page, written by Svante Odén himself. The article was part of the broadsheet's series 'Miljö för framtiden' [Environment for the future], which ran from September to December. The series afforded leading scientists space to present and discuss various environmental problems in depth. Odén's article immediately put acidification on to the day-to-day political agenda. ${ }^{8}$

The national side of the environmental debate also included mercury poisoning. In the summer of 1967 , it had been discovered that the fish in many Swedish lakes contained high levels of mercury. A ban on selling the fish was introduced. For commercial fishermen in Lake Vänern, Sweden's largest lake, the ban meant unemployment. The events attracted a lot of media attention. They showed that environmental toxins were a direct threat to human lives and livelihoods.

The eventful autumn of 1967 hence featured many themes, directions, and voices. Because of this, Hans Palmstierna came to play a special role. He spoke about humanity's survival and global issues, but he was also heavily involved in national and local problems - sometimes purely technical ones. In addition, Palmstierna moved in several different spheres. Not only was he active as a scientist; he also wrote regularly for Dagens Nyheter. Besides, he was an active Social Democrat. This combination of scientific,

7 Miljövårdsforskning. Betänkande del 1. Forskningsområdet (Stockholm: Ministry of Agriculture, 1967); Miliövårdsforskning. Betänkande del 2. Organisation och resurser (Stockholm: Ministry of Agriculture, 1967).

8 Lars J. Lundgren, Acid Rain on the Agenda: A Picture of a Chain of Events in Sweden, 1966-1968 (Lund: Lund University Press, 1998). 
media-based, and political capital gave him a unique platform from which to operate. ${ }^{9}$

The breakthrough of environmental issues in Sweden was intimately intertwined with that of Hans Palmstierna. In the autumn of 1967, he gained recognition as a scientific expert on environmental and future-orientated issues. Paul Warde and Sverker Sörlin have described this knowledge as a special type of scientific meta-expertise. They argue that postwar environmental concepts and scientific expertise about the future were co-produced. In their view, the concept of the environment had a temporal direction right from the start, a direction which pointed ahead to a looming catastrophe. Knowledge about future trends and scientific expertise in the environmental field were developed jointly as two sides of the same coin. ${ }^{10}$ But how did this happen in Sweden in the autumn of 1967 ?

\section{Hans Palmstierna as an alarm clock}

On Friday 27 October, Hans Palmstierna was interviewed at considerable length on the TV news. At that time there was only one television channel in Sweden, and the evening news was popular. During the programme, a copy of Plundring, svält, förgiftning was displayed. Its cover showed a picture of the tree of knowledge of good and evil. The book was fresh off the press, and Palmstierna was still unknown to most people. He told the reporter about the 'hugely complex poisoning we're being exposed to'. Against a background of pictures of smoking chimneys, sludge pouring from wastewater pipes, and traffic jams, he talked about lead, mercury, and phosphates. He added that famine was a permanent global condition. Within a decade it would hit us. The currently rising meat prices were a harbinger of a world with insufficient food, he said. ${ }^{11}$

That same day, Plundring, svält, förgiftning was featured in the country's biggest tabloid, Expressen (independent liberal). The paper claimed that the book was one of the most pessimistic to date. The writer asked: 'How long do we really have left on Earth? Ten years? Fifteen?' He emphasized that the most important thing happening

9 David Larsson Heidenblad, 'Boken som fick oss att sluta strunta i miljön', SvD, 23 October 2017.

10 Warde and Sörlin, 'Expertise for the Future'.

11 'Aktuellt', SVT, 27 October 1967. 
right now was that 'we are finally trying to measure the full extent of the catastrophe' and are 'starting to get close to the truth'. ${ }^{12}$ A few days later, the Scanian broadsheet Skanska Dagbladet described the book as 'the toughest, most concise reckoning imaginable with modern civilization's waste of nature's assets'. ${ }^{13}$ The book had an immediate impact. However, it took a couple of weeks for it to move into the main focus of the press.

In an editorial on 11 November, Dagens Nyheter discussed both Plundring, svält, förgiftning and the report submitted by the government enquiry into natural resources. Hans Palmstierna's book was described as a 'fact-packed and fascinating thriller about the state of the planet and humanity's needs'. Both the book and the report were highly recommended. The two texts could alert people and spur them to act. However, the editorial writer also felt that 'awareness of the environmental problems' was already well under way. Knowledge existed among politicians, industry, and the general public about what was happening and what had to be done. 'Nor is the will to act lacking', the writer stressed. In this way, grave insights into the crisis were combined with a measure of confidence. ${ }^{14}$

On the following day, Palmstierna's book was discussed on the editorial page of the social democratic tabloid Aftonbladet. The writer said that the book's author did not hold back in showing 'what an unsustainable development we've ended up in'. In a limited space, Palmstierna had taken a comprehensive approach to 'the gigantic complex of problems on whose solution the future depends'. What made Palmstierna's contribution particularly commendable was that he did not just focus on the problems. According to Aftonbladet, he was constantly looking for constructive solutions. His book placed some hope in socialism, scientific enquiry, and international solidarity. 'We have every reason to wish', concluded the editorial writer, 'that his book not only reaches Swedish readers but also reaches beyond our borders' ${ }^{15}$

Other voices in the press seized on the apocalyptic elements. In the liberal tabloid Kvällsposten, Staffan Ulfstrand wondered if we had come to the beginning of the end. The looming catastrophe

12 Ulf Nilsson, 'Hur lång tid har vi kvar på jorden?', Exp, 27 November 1967.

13 Ivar Peterson, 'Samhället plundrar våra naturvärden', Skånska Dagbladet (SkD), 2 November 1967.

14 Anon., 'Sent på jorden', DN, 11 November 1967.

15 Bengt Sjögren, 'Internationell planhushållning - ett livsvillkor', Aftonbladet $(A B), 12$ November 1967. 
would 'hit the whole planet'. There were no new continents to escape to. A few 'lunar and planetary journeys' would not solve the population problems. Plundring, svält, förgiftning was presented as insightful, well-documented, and shocking reading. It should be put in everyone's hands. ${ }^{16}$ However, Palmstierna's strident tone of voice was a matter of some concern. Many people will have felt that 'Palmstierna is peddling doom completely unnecessarily'. ${ }^{17}$ And was it not the case that the 'compelling facts of science' were starting to become 'like ordinary background music?', wondered the cooperative movement's weekly magazine $V i{ }^{18}$

Most press voices, however, agreed that Hans Palmstierna's book was an important alarm clock. The only critical voice was Nils Landell, writing in the right-wing broadsheet Svenska Dagbladet. $\mathrm{He}$ argued that the book was permeated by too much pathos and not enough facts. There should have been more examples and less 'irrelevant speculation'. In particular, Landell criticized Palmstierna's political position-taking, expressing his doubts that a socialist government would be best suited to tackle the serious problems. On the contrary, all nations, whatever their social system, should work to solve the global issues. ${ }^{19}$ Landell's criticism was of marginal importance, though, and it did not generate any discussion. The dominant opinion in the press was that Plundring, svält, förgiftning was interesting, accessible, and scientifically irreproachable. It was an important book which should be read by many.

\section{From knowledge to action}

On 21 November, Hans Palmstierna wrote about the report submitted by the government enquiry into natural resources in the article series 'Miljö för framtiden' [Environment for the future]. He began by pointing out that the mercury emissions from the pulp industry had caused mass unemployment in the fishing industry. The biocides threatened higher forms of wildlife. The phosphates in detergents had caused algal bloom in lakes, and the sulphur in the acid rain posed a great danger. All of these problems had come to the public's attention. 'Many surprises are still in store', he wrote.

16 Staffan Ulfstrand, 'Början till slutet (?)', KvP, 15 November 1967.

17 Bertil Walldén, 'Klockan var mer än vi trodde', Vestmanlands läns tidning (Vlt), 15 November 1967.

18 Anders Clason, 'Katastrofskval', Vi, 18 November 1967.

19 Nils Landell, 'Väckarklocka mot förgiftning', SvD, 20 November 1967. 
Future government enquiries would probably 'present equally unpleasant revelations'.

How had we put ourselves in this situation? Why had we ruined our environment to the extent that our living conditions were threatened? Palmstierna was clear about the answer: 'We wanted a rapidly rising standard of living.' To make this possible, production had focused on making things as cheaply as possible with no regard to the long-term consequences. Equally catastrophic was the fact that 'we prefer to forget about the goods we have consumed'. By paying the lowest possible price for waste disposal, it had been possible to raise the standard of living very quickly. But nature had not yet presented its bill. 'Will it be so high that we cannot pay it?' he asked.

Palmstierna pointed out that the 1964 government enquiry into natural resources had been commissioned in order to gain an overview of the situation. Its report provided 'an extremely clear and easyto-read survey' of the nature and seriousness of the problems. The report could be read by anyone who was interested in the issues. Palmstierna stressed that the government enquiry presented new and frightening facts, including Svante Odén's findings about acid rain. It also provided insight into 'the very limited knowledge we so far possess'. To remedy this, target-orientated research and greater research resources were required. State-authority inspections of industries and municipalities should also be intensified.

Palmstierna emphasized that politicians needed comprehensive information from experts in order to make well-considered decisions. The government enquiry into natural resources had now supplied this. What was lacking, though, was a preliminary action programme. Such a programme could complement the information and make it more useful to politicians. The costs should not be a deterrence factor. People's individual standard of living could not be allowed to 'continue to rise at the expense of our future health and our children'.

Palmstierna concluded the article by pointing to an American enquiry which had exposed even more frightening facts than the Swedish one. In that regard, he said, Sweden was fortunate in being ten years behind the United States. However, the American enquiry did make a couple of concrete proposals which he valued. The first was to return consumed material to the production process as much as possible. Developing rational 'circular processes' would make it possible to avoid the worst damage. The second suggestion was to establish an experimental city in which new technology could be 
tested at the state's expense. Successful innovations and systems could then be spread throughout the country. Such a city could also be used to train environmental conservation experts, a professional group which Palmstierna felt there was a great need to establish. ${ }^{20}$

Palmstierna's article displayed his broad range. There was no doubt about how seriously he regarded the situation, but it was also clear that he perceived considerable scope for action. Palmstierna was concrete and forward-looking. He also showed great faith in politics, technology, and science. This relationship has been highlighted by Jonas Anshelm, who argues that Palmstierna's approach hence did not challenge the Social Democrats' traditional progressivist optimism. This relationship was crucial, Anshelm says, when Palmstierna came to be given a key political role as the Social Democrats' environmental policy was being formulated. ${ }^{21}$ In the autumn of 1967, though, Palmstierna did not have such a role; he had not yet been offered any political mandates. His expertise on environmental and future issues was becoming entrenched, however. The decisive factor was that he was perceived as a man of action.

In early December, Dagens Nyheter published an extensive and highly appreciative review of Plundring, svält, förgiftning. The expressive headline was 'From knowledge to action'. The review was written by the author and engineer Sven Fagerberg. Fagerberg was an influential voice in the Swedish public debate of the 1960s, and he had been discussing crucial global issues for a long time. His review proceeded from the progressivist optimism which he felt had characterized society's leaders during the early postwar period, especially in the technological field. 'The clear advances made in many places seemed to confirm that we were on the right track.' Over time, though, the picture had begun to darken. Question marks were raised about the global use of resources and the direction of development. 'Our prosperity rests on a false foundation', he asserted, 'on a degradation process of a one-way nature.' This meant that we were stealing 'from future generations - our own and, not least, those of developing countries'. This was a 'bitter truth' which political parties and interest groups found difficult to accept because their leaders had been shaped by the early postwar optimism about progress. The new perception of major problems conflicted with

20 Hans Palmstierna, 'Vår smutsade värld', DN, 21 November 1967.

21 Anshelm, Socialdemokraterna och miljöfrågan, p. 18. 
that optimism. The leaders therefore clung to an outdated worldview. Still, Fagerberg said that they did not do this out of ill will, but because of innocence and incompetence.

Nonetheless, the disastrous situation was obvious. 'The problem is', Fagerberg wrote, 'how to make the existing knowledge come alive.' This is what he felt Palmstierna did in such a praiseworthy manner. The book was 'very well supported by facts'; but it was at the same time compelling and action-orientated. Palmstierna's greatest merit was that he belonged 'to the few scientists who feel their responsibility and realize that they must intervene in the practical course of events'. In addition, he 'was constantly indicating ways to take practical action'. This, Fagerberg felt, contained 'a measure of effort, of vitality' which was absolutely necessary. Anyone who wanted to change the world had to take risks. 'If we wait until light has been shone into every dead-end corner of a set of problems, we will be too late.'

Sven Fagerberg's review portrayed Hans Palmstierna as a courageous scientist with a broad orientation and a sense of responsibility. Fagerberg hoped that Plundring, svält, förgiftning could make environmental conservation a key political issue. Perhaps Sweden could even become a pioneering nation? In conclusion, he emphasized that the country had a good economy, high technological expertise, and skilled researchers. In addition, no resources were being wasted on military ambitions or space rituals. 'We are practical by nature and think best about material things', he wrote. 'We are not really interested in anything at all and are thus free to become involved. ${ }^{22}$ The time for environmental protection and Hans Palmstierna was now.

Sven Fagerberg's review is one of the clearest examples of how knowledge about a looming environmental crisis and Hans Palmstierna's future-orientated expertise were being co-created in the autumn of 1967. However, Fagerberg was far from being alone in his assessment. On the contrary, at the beginning of December there was great unanimity in the Swedish public arena that Palmstierna was a knowledgeable, pragmatic, and action-focused environmental debater. In the liberal broadsheet Göteborgs Handels- och Siöfartstidning, Bengt Hubendick, one of the most high-profile ecologically orientated voices in Sweden at this time, wrote that Plundring, svält, förgiftning should be distributed to 'everyone in a

22 Sven Fagerberg, 'Från kunskap till handling', DN, 3 December 1967. 
position of political and technological responsibility' along with 'demands to read it through and ponder it'. ${ }^{23}$ In the likewise liberal broadsheet Göteborgsposten, Göran Michanek stated that Palmstierna had achieved something new. He had shown that environmental destruction was not a far-off threat of disaster: it concerned us and our children. ${ }^{24}$ It was high time to move from knowledge to action.

\section{Science, politics, and the limits of expertise}

In December, the widespread support for Hans Palmstierna and his book Plundring, svält, förgiftning contrasted with the intensive debate that arose over Människans villkor. The two debate books were outwardly very similar, but they came to be perceived in very different ways. The ensuing pages review the reasons why this happened and what the consequences were.

On Thursday 7 December, the day before Människans villkor reached the bookshops, it was featured in the televised weekly magazine Monitor. The broadcast began with three terms rolling past on the screen: global fire, global famine, global poisoning. Then pictures were shown of starving, emaciated children from the developing world. The powerful images were ironically accompanied by a sung version of 'God who holds the children dear', the most widespread evening prayer for children in 1960s Sweden.

The unsettling opening scene of the programme was followed by Georg Borgström, filmed in his office and surrounded by books, talking about global injustices, malnutrition, and overpopulation. He emphasized that we were in the initial stages of a monumental crisis' and that we must all take off our blinkers. 'An unpleasant reminder in the midst of the early Christmas rush, isn't it?' said the narrator, whereupon photos of chimneys, car-exhaust emissions, and polluted watercourses were shown. 'Pictures like these also arouse discomfort', continued the voice; 'we are pouring toxins and gases and dangerous substances into nature and over ourselves, with consequences that we know far too little about. Only that they may be devastating.'

Monitor continued by interviewing several of the researchers behind the book. Ecologist Bengt Lundholm, who had been the secretary of the 1964 government enquiry into natural resources,

23 Bengt Hubendick, 'Nu är det allvar', Göteborgs Handels- och Siöfartstidning (GHT), 4 December 1967.

24 Göran Michanek, 'Väckarklocka med skräll', GP, 29 November 1967. 
talked about DDT and mercury. Physicist Tor Ragnar Gerholm focused attention on the world's nuclear weapons. Carl-Göran Hedén, professor of bacteriology at the Karolinska Institute, criticized the prevailing political system. He felt that the national organization and the short legislative terms were a fragile foundation on which to stand in a situation where the survival of the human species was at stake.

The programme concluded with a studio debate between Lars Gyllensten and the Social Democratic government minister Krister Wickman. In this section, the order was reversed. It was not the scientist Gyllensten who held the politician Wickman to account but vice versa. The government minister spoke first. He rejected the image of politicians painted in the book. The researchers seemed to believe that politicians 'are cynically exploiting an easily led, ignorant mass of voters'. This view revealed a deep contempt for politicians but, even more seriously, a contempt for voters. Did Gyllensten want to replace political democracy with rule by technocratic experts?

The debaters' body language was significant. Wickman sat leaning forward in an assertive position, whereas Gyllensten looked down at the floor. He averred that he was not attacking democracy, nor did he despise politicians and voters. All he wanted was greater scientific influence. Wickman then steered the conversation on to the topic of long- and short-term goals. The two men discussed the role played by politicians in creating public opinion. On this point there was considerable agreement. Both felt it was the politician's task to lead and shape opinions, not merely to implement what was possible at any particular time. Wickman ended by underlining that the whole problem was to a large extent a 'matter of knowledge and awareness'. He conceded that for a long time society had underestimated the risks in the environmental field. But right now 'we are experiencing a really noticeable change in attitude about these issues'. The conditions for reaching a solution were good. In this way, Monitor came to a mildly optimistic and reassuring conclusion. ${ }^{25}$

The next day, the press reported on both the television programme and the book release. ${ }^{26}$ Svenska Dagbladet also published an initial review. It characterized the scientists' initiative as commendable in

25 'Monitor', SVT, 7 December 1967.

26 Rune Johansson, 'Hotet mot mänskligheten', DN, 8 December 1967; Gall, 'Syndafloden som stiger', SvD, 8 December 1967. 
principle but not very constructive in practice. Their book contained no suggestions for 'concrete political measures' but only 'well-meaning and vague prescriptions'. The reviewer wondered whether 'a few concrete instructions' might have been given to politicians instead of 'just generally scolding them and declaring them out of date?' Such an approach might have assisted in the building of a willingness to cooperate. ${ }^{27}$

A few days later, Aftonbladet's editorial page continued along the same lines. It welcomed scientists intervening in the public debate. But it strongly condemned the contempt for politicians - and ultimately for voters - expressed in the book. Carl-Göran Hedén and Lars Gyllensten were particularly singled out for criticism. They seemed to regard scientists as enlightened truth-seekers and politicians as power-hungry deceivers. The editorial writer stressed that this type of contempt was a 'fruitless starting point' for establishing greater cooperation. In addition, the researchers 'had cheerfully helped to create the technological advances which now constitute deadly threats to humanity'. It was therefore an 'unusually unjustifiable arrogance' to portray scientists, as opposed to politicians, as 'moral clean-living types'. ${ }^{28}$

Criticism was harsh on Dagens Nyheter's editorial page as well. The book's subtitle in itself prompted questions. Why were scientists only addressing politicians? Did the big questions of the future not concern everyone? The editorial writer stressed that societies neither could nor should be led by 'hierarchical elite networks of researcherspoliticians-engineers'. In addition, a lot was beginning to happen in the world. Both in Sweden and abroad, people were starting to take the environmental dangers more and more seriously. While important to this development, politicians and researchers 'were not more central than other influencers and power factors in society'. ${ }^{29}$

Of the twelve scientists behind Människans villkor, only CarlGöran Hedén tried to respond to the criticism. He said that he considered politicians to be a great resource but that party politics posed a serious danger. As far as possible, it should be replaced by 'the scientific method'. For Hedén, it was not a question of whether scientists or politicians were the morally superior category. It was about different ways of working. He preferred the scientific method and argued that it should have more influence on how society was

27 Thure Stenström, 'Naturvetarna och världens nöd', SvD, 8 December 1967.

28 Anon., 'Forskare diskuterar politik', AB, 12 December 1967.

29 Anon., 'Vetenskap och politik', DN, 11 December 1967. 
governed. Hedén praised 'dynamic real democracy', by which he meant frequent referendums on specific issues. ${ }^{30}$

Hedén's contribution, however, did not pour any oil on the troubled waters. Throughout the month of December, Människans villkor continued to be criticized in the press. There was widespread insistence that the scientists raised important issues, but also that they evinced elitist and anti-democratic tendencies. ${ }^{31}$ The Liberal Party politician Carl Tham (later a Social Democrat) was especially censorious. He argued that the researchers' attack on the politicians had a 'disquieting kinship' with the criticism of 'the principles of democracy previously asserted by the far right'. ${ }^{32}$ In this context, it is noteworthy that the book's editor, Karl-Erik Fichtelius, did not participate in the debate. This may seem surprising, as Fichtelius was an experienced debater; but the reason is that he was in the US on a lengthy stay as a visiting researcher. ${ }^{33}$

The extensive and unanimous criticism of Människans villkor shows that there were sharp limits on scientific expertise in 1960s Sweden. Researchers were welcome to define problems, spread knowledge, and shape opinions. But when they moved into the field of political decision-making in a confrontational manner, they encountered strong opposition. At the same time, the attention paid to Människans villkor undoubtedly helped to circulate knowledge about a global environmental crisis among the general public. Both in the book and in the press debate, it became clear that many people had begun to regard environmental destruction as a connected set of problems intimately linked with other issues of survival. However, scientific expertise about the future circulated in an ambivalent manner. Some researchers, such as Lars Gyllensten and Carl-Göran Hedén, were viewed with scepticism and suspicion. By contrast, Hans Palmstierna would further strengthen his own position.

30 Carl-Göran Hedén, 'Ett genmäle om vetenskap och politik', AB, 19 December 1967.

31 Jean Braconier, 'Utmaning till politikerna', Sydsvenska Dagbladet (SDS), 15 December 1967; Folke Johansson, 'Vetenskapsmän och politik', Upsala Nya Tidning (UNT), 21 December 1967; Anon., 'Politik och vetenskap', KvP, 30 December 1967; Erik Hjalmar Linder, 'Debatternas år', GP, 31 December 1967.

32 Carl Tham, 'Forskare och politiker', DN, 20 December 1967.

33 Letter from Karl-Erik Fichtelius to Per Gedin, 5 January 1968, vol. 106, Albert Bonniers förlag II (publisher's archive), Centre for Business History. 


\section{The consolidation of Hans Palmstierna's expertise}

In the lively debate about Människans villkor, reference was often made to Plundring, svält, förgiftning. However, the growing criticism against scientists was never levelled at Palmstierna. On the contrary, his book continued to be praised. On 13 December, the liberal broadsheet Sydsvenska Dagbladet singled it out as one of the 'most acerbic, most ingenious, best informed, and best presented' debate contributions made in Sweden in a very long time. It was underlined that Palmstierna had a broad education, not only in the natural sciences but also in the humanities. He was able to go beyond his own narrow area of expertise and dared to comment on the really big issues. 'And this is surely what is necessary', wrote the reviewer, 'that there is an elite of fearless debaters with a broad enough frame of reference to be able to think in an interdisciplinary way'. ${ }^{34}$

The emphasis on Palmstierna's great breadth and wide-ranging knowledge was typical of how his expertise circulated. Another key aspect was that he was characterized as an optimist. In the words of one writer, people might have presumed that 'Palmstierna with all his knowledge' would long ago have stopped believing in the value of appealing to 'individual or collective reason'. But this was not the case. Although he saw the seriousness of the situation, Palmstierna was an optimist who believed in people. Joint efforts could 'avert the impending misfortunes'. ${ }^{35}$

On Christmas Eve 1967, Gösta Bringmark wrote a column in the largest social democratic broadsheet, Arbetet, based on the biblical story of the expulsion from the Garden of Eden. Bringmark said that modern humans had now learned that 'knowledge really is both good and bad'. He underlined that 'our technology is killing our own existence' and that 'humanity is a diseased organism in nature or a parasite on the Earth'. The speed at which these views had become established was astounding, he said. Environmental issues had 'finally begun to break through on a broad front'. Even so, Bringmark was concerned that a rift between scientists and politicians was being created. 'It is of the utmost importance that this chasm does not deepen', he urged. The person who guaranteed that it would not was Hans Palmstierna. Better than anyone else,

34 Lars Holmberg, 'Giftvatten, snuskland', SDS, 13 December 1967.

35 Erik Nyhlén, 'Vår nedsmutsade värld', Borlänge Tidning (BoT), 18 December 1967. 
he had been able to take a 'concise and motivating approach' to the momentous matters of destiny. ${ }^{36}$

The contrasts in how the Swedish press handled the contributions of the various scientists were striking. The knowledge they cited was largely the same; but the way in which the researchers' expertise circulated differed. Palmstierna was presented as reasonable and politically concrete, whereas the researchers behind Människans villkor were regarded as arrogant and vague. This contributed to a further strengthening of Palmstierna's position. Among a growing chorus of scientific warning voices in the late autumn of 1967, he stood out as sensible and pragmatic.

In addition, Palmstierna had access to a key media platform: Dagens Nyheter's culture page. In the 1960s, the newspaper held a leading position in the Swedish public debate and was a driving force behind getting environmental issues onto the agenda, not least through Barbro Soller's journalism. Hired as a general reporter for the newspaper in 1964, she gradually developed into an environmental reporter. Soller became Sweden's, and one of the world's, first full-time and on-staff environmental journalists. ${ }^{37}$ Besides, Dagens Nyheter made several efforts to bring in scientists as writers in the newspaper. The article series 'Miljö för framtiden' was crucial in this respect. Only one scientist was given the opportunity to write two articles for it: Hans Palmstierna.

On 29 December, 'Insikt, kunskap, handling' [Insight, knowledge, action] was published. It was the ninth and final part of the article series. Palmstierna began by stating that 'the realization that the Earth is small, and that humanity has the power to destroy its own possibilities of continuing to live, dawned late'. This realization, he argued, had begun to take shape when the atomic bombs fell on Hiroshima and Nagasaki, but no 'mass movement' had ever arisen. Instead, people became used to 'living under the threat of annihilation'. In the shadow of the bomb, however, new insights had emerged. Researchers had gradually discovered that many industrial processes were highly risky for 'the nature we live in and live off'. The environment was more sensitive than we had thought.

Palmstierna stressed that we have now 'brutally experienced that the Earth is small and life fragile'. These insights were no longer

36 Gösta Bringmark, 'Människan som parasit eller Kunskapens träd på gott och ont', Arbetet (Arbt), 24 December 1967.

37 Djerf Pierre, Gröna nyheter; Larsson Heidenblad, 'The Emergence of Environmental Journalism'. 
'the property of a small minority', he wrote, 'but now belong to the general public'. However, it had taken a long time to reach this crucial point. The scientists, who had sensed the risks intuitively for a long time, had not had 'enough evidence to be able to convince'. Palmstierna claimed that society had 'demanded too much detailed knowledge before it wanted to believe the warnings'. Many people had reacted unfavourably to the scientists' insights and rejected them.

The reason, Palmstierna said, was that the lines of communication between scientists and politicians had not worked. 'There is still no calm and trust-based dialogue', he wrote. For that reason, 'a new group of interpreters must be singled out from among the ranks of the scientists'. These people would be able to 'translate the findings and warnings of science into clear and distinct normal prose, so that $[. .$.$] the authorities and the general public can acquire a true$ picture of what is happening'. This was the role he took upon himself. It was the first necessary step towards having a viable environment. The aim was to create readiness among politicians and the general public to accept the intrusive and costly measures that the situation required. Nor could these information efforts stop at national borders. The problems were transnational, and so the scientists' opinion-building work had to be transnational too.

In conclusion, Palmstierna again stressed that the individual standard of living could not be allowed to rise further at the expense of the shared environment. If this continued, we would soon no longer have 'any viable environment to live in - and live off'. $\mathrm{He}$ underlined that in this serious situation, optimism about progress was not warranted; but nor was pessimism. 'We must [...] face the facts', he wrote, 'and act rationally on the basis of the knowledge we possess.' Only in this way could we guarantee that our generation, as well as future ones, 'will survive in a manner compatible with human dignity'. ${ }^{38}$

Palmstierna's article concluded the Swedish environmental debate of 1967. As a result of his and other scientists' actions, that debate had changed fundamentally in a brief period of time. Knowledge of a global environmental crisis and scientific expertise regarding the future were now circulating intensively in the Swedish public sphere. However, a social knowledge breakthrough cannot be fully studied by examining the public sphere alone. What happens

38 Hans Palmstierna, 'Insikt, kunskap, handling', DN, 29 December 1967. 
there is important; but there are other arenas which are also decisive for how knowledge moves and operates within a society. In the following section, I will therefore shed light on the breakthrough of environmental issues on the basis of two meetings held in the corridors of power.

\section{Forskningsberedningen's meeting on environmental conservation issues}

On Monday 4 December 1967, Forskningsberedningen (the advisory council on research), chaired by Sweden's prime minister Tage Erlander, met to discuss research on environmental conservation. Despite its name - beredning in Swedish has connotations of preparation and drafting, especially in a legislative context Forskningsberedningen was not a preparatory body. It functioned as a meeting place for politicians, scientists, and other key figures in government and industry, having been set up in 1962 in order to deepen cooperation between them. The starting point was that research was thought to play a key role in the development of society. Forskningsberedningen was a step towards a more active government research policy. Its significance was highlighted by the fact that the Swedish prime minister himself chaired its work. ${ }^{39}$

The meeting on 4 December brought together forty-seven people, including a large number of government ministers, professors, and directors of various authorities. In addition to the regular participants in Forskningsberedningen, fourteen individuals had been summoned especially to attend on this particular occasion. They included Hans Palmstierna and Svante Odén. Forskningsberedningen undoubtedly assembled a social elite, and the question is how knowledge and expertise circulated in such a context.

The meeting began with a long speech by Prime Minister Erlander. $\mathrm{He}$ said it was now obvious that 'our environment is seriously threatened'. The warning signals were coming more and more often, both in Sweden and abroad. Lakes were eutrophying, acid rain was

39 Peter Stevrin, Den sambällsstyrda forskningen: En sambällsorganisatorisk studie av den sektoriella forskningspolitikens framväxt och tillämpning $i$ Sverige (Stockholm: Liber, 1978); Rune Premfors, Svensk forskningspolitik (Lund: Studentlitteratur, 1986); Tunlid and Widmalm (eds), Det forskningspolitiska laboratoriet; Per Lundin, Lantbrukshögskolan och reformerna: Frän utbildningsinstitut till modernt forskningsuniversitet (Uppsala: Swedish University of Agricultural Sciences, 2017), pp. 109-110. 
falling from the sky, and fish were becoming contaminated. The ongoing poisoning was worsening the conditions for agriculture and forestry. Plant and animal life was being threatened. 'Are we on the way', the prime minister wondered, 'towards gradually, and partly imperceptibly, making our existence impossible through environmental destruction?'

Erlander continued his speech with a historical review. He emphasized that 'in a situation of highly obvious material shortages, the environment comes in second place'. Because this had previously been the case, the overarching political goal had been said to consist in 'creating increased production, creating jobs, rapidly raising the standard of living'. As a result, the environment in Sweden, as in other industrialized countries, had been exploited to secure 'basic material needs'. Erlander emphasized that 'not for one moment' should anyone underestimate what this technological and economic development had meant to people. It had enabled 'increased consumption, greater social security, more leisure time, and a number of other [good] things'. This development would continue to be safeguarded, but the environment must be 'taken into account in a completely different way than it used to be in the past'.

Erlander proposed that environmental issues should be perceived as 'part of the social reality experienced by the individual' to a greater degree than before. As the standard of living increased, so did the demands on the environment. 'Stemming the destruction of nature, pollution, and poisoning' would ensure security. Achieving this aim called for cooperation between the central government, municipalities, and the world of business. It was unreasonable, Erlander felt, to demand that individual companies be able to perceive the long-term environmental consequences of their own operations. Environmental problems were an issue for society as a whole. It was at the political level that rules and boundaries had to be set. This required 'a shared sense of values' and acting in solidarity.

Towards the end of his speech, the prime minister adopted an existential tone and looked ahead. He acknowledged that it was 'easy to feel powerless when faced with the dimensions of the environmental problems', but said that people did not have to feel that way. 'We have greater economic resources than ever', he pointed out, adding that 'researchers have made pioneering efforts to make us aware of the urgency of the environmental problems.' Of course, greater knowledge and a balanced overview were required; but 'ultimately everything depends on what we are willing to do'. Erlander stated that the government was prepared to go further, adding that 
'the distance between knowledge and action must be as short as possible'. New research and new technology would be developed. 'What today's discussion is about', he concluded, 'is how, with the help of research, we can secure a viable environment for humanity, an environment that we can pass on to future generations. ${ }^{40}$

Erlander's speech shows that, at that time, environmental issues had taken root at Sweden's highest political level. The prime minister was fully aware of their seriousness. His insistence that a rapidly rising standard of living had had unforeseen consequences echoed the description of events by Palmstierna and other debaters. One important difference, though, was that Erlander was very careful to emphasize the favourable aspects of development as well. People had become better off. The material advances were real and desirable. The clock would not be turned back. It was his hope that research and politics could deal with the unwanted side effects and ensure continued positive social development.

The subsequent discussion was based on the report of the government enquiry into natural resources. In particular, organizational issues were debated. The enquiry had proposed that an advisory council on environmental issues should be established under the direct leadership of the minister for agriculture. This council would be mandated to fund both basic research and goal-orientated research. Many of the professors who were present welcomed this proposal. They argued that research needed more resources if it was to be able to change society. At present, a shortage of researchers and insufficiently attractive project positions posed obstacles to success. If the government was serious about its new focus, the basic grants had to be increased. It was not possible to either attract or retain the best researchers with one- and two-year contracts. ${ }^{41}$

The organizational relationship between the new National Environment Protection Board and the proposed Environmental Advisory Council [miliövardsberedningen] was the subject of intense debate. Those participants in the meeting who were doing active

40 The minutes of the meeting are among Birgitta Odén's bequeathed documents, which are being stored at the Department of History in Lund while awaiting formal archiving. They consist of two binders, referred to in this book as BO 1 and BO 2. BO 1, 'Statsministerns anförande vid Forskningsberedningens sammanträde den 4 december 1967' [The prime minister's speech at the meeting of Forskningsberedningen on 4 December 1967], pp. 1-5.

41 BO 1, 'Mötesprotokoll från forskningsberedningen 4 december 1967’, pp. 4-5, 7-9, 12, 14-15. 
research stressed the value of independence while other voices argued that a coordinated approach could shorten the step from research to action. Lars Brising, who was director-general of engineering in the Swedish Air Force, said that 'there was everything to gain' from making the National Environment Protection Board an 'expert and thereby forceful executive institution'. ${ }^{42}$ The value of coordination was also emphasized by Martin Fehrm, director-general of the Swedish National Defence Research Institute (FOA). He stressed the importance of 'utilizing the results of research when undertaking social planning', adding that it was important for existing knowledge to be fitted into 'a model plan or overall picture' as soon as possible. According to Fehrm, this type of systems analysis was 'one of the most important elements of goal-orientated environmental conservation research'. He also underlined that the cost estimates supplied by the government enquiry into natural resources were at the lower end. If the government was serious about 'attacking the naturalresource problem', it should be prepared for 'significantly higher costs'. ${ }^{43}$

The economic aspects were also highlighted by Erik Dahmén, professor of economics at the Stockholm School of Economics. He said that there were 'very strong socioeconomic reasons' for taking measures against environmental degradation and lending greater depth to environmental research. Dahmén felt that any 'sacrifice of environmental values' needed to be perceived as costs - just like 'raw materials, capital, and labour'. Currently there was no price mechanism in operation, which meant that 'short-term consumption preferences' were favoured at the expense of environmental values. ${ }^{44}$ Dahmén would further develop these ideas the following year in his high-profile debate book Sätt pris på miliön: Sambällsekonomiska argument $i$ miljöpolitiken [Put a price on the environment: socioeconomic arguments in environmental policy] (1968)..$^{45}$

Bank director Tore Browaldh continued along the same lines as Dahmén. He drew attention to the possibility of 'solving the environmental problems in the long run by utilizing market-price formation'. This could be done, for example, by putting a special tax on environmentally unfriendly products. However, Browaldh stressed

42 Ibid., p. 8.

43 Ibid., p. 6.

44 Ibid., p. 9.

45 Erik Dahmén, Sätt pris på miliön: Samhällsekonomiska argument i miljöpolitiken (Stockholm: SNS, 1968). 
that a tax policy specific to Sweden risked doing hefty damage to Swedish companies which operated in a highly competitive international market. Even so, he suggested that Dahmén should be mandated to lead a working group that could develop a proposal as to how market-price formation might be designed and introduced in the environmental field. Browaldh further envisioned that a powerful research effort in the environmental field could in due course lead to the creation of a new Swedish industrial sector in environmental technology.

Another aspect that was repeatedly mentioned was the need for international cooperation. On this subject, there was widespread agreement but also some concern. Sune Bergström, professor of medical and physiological chemistry at Lund University, said that there was a great lack of knowledge and interest within the Organisation for Economic Co-operation and Development (OECD). Only 'a few member states' were 'aware of the seriousness of the problem'. For this reason, Sweden could not passively await future international agreements. Instead, we should strive to become 'a pioneering nation and, through this primary effort, promote interest in the issue in other countries'. ${ }^{46}$ Nobel Laureate Arne Tiselius, professor of biochemistry at Uppsala University, also felt that the government should be proactive. He suggested that Sweden should encourage the establishment of an international research council which might assume strategic responsibility for initiating 'urgent targeted research'. ${ }^{47}$

Towards the end of the meeting, Hans Palmstierna spoke. Stressing 'the need to inform the public', he also argued that biologists should be employed 'to a significantly greater extent' in order to inform engineers. Palmstierna agreed with Dahmén's comment that 'excessive consumption benefits' had been extracted, with 'destroyed nature as the result'. However, he emphasized that the distribution was uneven. The one who destroyed nature and profited from it was seldom the one who was adversely affected as a result. There was an injustice here that must not be forgotten. ${ }^{48}$

Clearly, then, the Forskningsberedningen meeting had significant points in common with the public environmental debate. Knowledge and expertise circulated in similar, though not identical, ways. The main difference was that this meeting - with the exception of

46 BO 1, 'Mötesprotokoll från forskningsberedningen 4 december 1967', p. 11. 47 Ibid., p. 14.

48 Ibid., p. 15. 
Tage Erlander's introductory speech - did not talk about environmental issues in terms of humanity's survival. It is also striking that overpopulation and global injustices were not discussed. At this meeting, the environmental problem was more narrowly defined. There was no talk of a crisis or a future global catastrophe. The discussion was primarily coloured by the report of the government enquiry into natural resources and the more low-key manner in which that report discussed environmental issues. The apocalyptic framework, much to the fore in the public debate, was not important here.

\section{A meeting at the Swedish National Defence Research Institute (FOA)}

On 27 November, a week before the meeting of Forskningsberedningen, another meeting was held at FOA. That meeting also addressed the question of how research might contribute to the development of society. The focus, however, was not on scientific and technical expertise but on the social sciences and humanities. This was because director-general Martin Fehrm felt that the environmental problems were ultimately bound up with human actions and political decisions. Consequently, scientific and technical knowledge was not enough. In order to give politicians a sufficient basis for decision-making, other skills were required as well. ${ }^{49}$

In May 1967, Martin Fehrm had convened an initial meeting at FOA. Among those invited were three professors: economist Assar Lindbeck, political scientist Pär-Erik Back, and historian Birgitta Odén. At this first meeting, they made it clear to Fehrm that the knowledge he requested did not exist. Researchers had not previously been interested in the historical, political, and economic dimensions of environmental issues. New research efforts were required to produce this knowledge. As a result, the concept of a joint research programme was born.

Another issue that was raised was how to make politicians and the general public realize the seriousness of the situation. Fehrm himself regarded the destruction of the environment as a security threat, comparable to other external threats to society's continued existence. The other participants supported this view. The discussions resulted in the idea of writing a joint debate book. Birgitta Odén

49 What follows is based on Larsson Heidenblad, 'Miljöhumaniora på 1960talet?', pp. 44-45. 
was mandated to draw up the guidelines for such a book. On 27 November she presented a discussion paper.

The form she envisioned was 'a modest publication, as accessibly written as possible. In other words: a serious pamphlet, intended to provoke discussion.' In order to have an impact it needed to be published with all due despatch, preferably as early as the spring of 1968 . The idea was that experts would speak up and awaken politicians and the general public to an understanding of the 'seriousness of the issue and the necessity of rapid targeted research'. Her memorandum, totalling five pages, contained a detailed synopsis which included a list of suggested writers. She placed special emphasis on the preface, which should be written by 'a person who was heeded by public opinion'. The theme should be 'the unintended consequences of the development of prosperity and technology and their disastrous consequences for the future of our children'. The person to whom she wished to entrust this task was the Social Democratic politician and diplomat Alva Myrdal, who worked with disarmament issues at an international level. ${ }^{50}$

The preface would be followed by an introduction containing the group's joint programme statement. This would assert that environmental destruction was 'such a serious threat to our future prosperity that it can be equated with a military security risk'. It was this circumstance that justified FOA's assuming the leadership of the operation. The aim of the research would be 'to acquire better information in order to guide the people who are making the crucial decisions'. The proposed author was Martin Fehrm, with the participation of the whole group. ${ }^{51}$

The ensuing three chapters would examine historical examples of disastrous environmental destruction, political decision-making processes in the environmental field, and the issue of how scientific information was disseminated within political bodies. Birgitta Odén and Pär-Erik Back could assume special responsibility for these parts of the publication. Six chapters of a scientific, medical, and security nature would follow. These would include one chapter by Svante Odén on the acidification caused by precipitation, one by Hans Palmstierna on public-health issues, and one by FOA chief engineer Erik Moberg on the Baltic Sea and Sweden's security policy. The purpose of the last-mentioned chapter was to show that 'the pollution of the Baltic Sea may lead to the Soviet Union making demands on

50 Birgitta Odén, 'PM 1' ['Memorandum 1'], November 1967, BO 1, p. 1.

51 Ibid., pp. 1-2. 
us, demands which we may find difficult to meet'. The question, however, was whether this could be said openly or whether it should merely be implied. ${ }^{52}$ The Cold War context - in which Sweden sought to maintain a neutral position - was much in evidence here..$^{53}$

These chapters, with their concrete problem descriptions, would be followed by a chapter which addressed environmental destruction from a national-economic perspective. This chapter could show that the cost calculations for basically all industrial production were too low 'if the cost of restoring nature is not also included in the calculation'. The chapter would culminate in a plea for 'realistic cost calculation' and a discussion of ' $w$ here the costs of environmental restoration should be taken from'. The thirteenth and final chapter would outline a comprehensive approach to the environmental issues. In this chapter, Martin Fehrm's task would be to emphasize how the ongoing environmental destruction was having adverse effects on human beings in virtually all areas. He would especially highlight the economic, health, and security-policy dimensions of the threats. The key word was 'coordination' of both the research efforts and the political decisions. ${ }^{54}$

Nothing, however, came of these plans for a joint publication. At the top of one of the copies of her memorandum notes, Birgitta Odén has briefly written 'rejected'. ${ }^{55}$ Possible explanations for this can be found in the document entitled 'Min föredragning' [My presentation]. In this document, Odén herself raised the question of whether a joint publication was in fact necessary. 'Or has the situation changed after the DN debate, Palmstierna's book, the report from the government enquiry into natural resources, and the actions of the National Environment Protection Board?'56 Her questions

52 Ibid., pp. 2-3.

53 In recent years, environmental history research has increasingly drawn attention to the significance of the Cold War context. See Ronald Doel, 'Constituting the Postwar Earth Sciences: The Military's Influence on the Environmental Sciences in the USA after 1945', Social Studies of Science 33.5 (2003); John R. McNeill and Corinna R. Unger (eds), Environmental Histories of the Cold War (Washington, DC: German Historical Institute, 2010); Jacob Darwin Hamblin, Arming Mother Nature: The Birth of Catastrophic Environmentalism (Oxford: Oxford University Press, 2013); Joshua P. Howe, Behind the Curve: Science and the Politics of Global Warming (Seattle: University of Washington Press, 2014).

54 Birgitta Odén, 'PM 1', November 1967, BO 1, pp. 1, 4-5.

55 Birgitta Odén, 'PM 1' (copy with margin notes), November 1967, BO 1, p. 1.

56 Birgitta Odén, 'Min föredragning', November 1967, BO 1. 
testify to the relevance of the matters raised in this chapter. Between May and November 1967, the Swedish environmental debate had undergone a fundamental change. Knowledge and crisis insights no longer circulated only in specific circles, such as those at FOA, but were moving with great intensity within the public sphere. Politicians and the general public had woken up.

But how much can we really know about the latter category? Is it possible to study the breakthrough of environmental issues in the autumn of 1967 from the perspective of the Swedish general public? What traces remain of those people who did not belong to a social elite which expressed itself in print? It is not easy to answer these questions satisfactorily. However, Hans Palmstierna's rich personal archive does contain a few examples. The earliest I have found comes from an unknown Gothenburg resident named Sören Gunnarsson. In October 1967 he contacted Palmstierna, initiating a correspondence. The following section takes a closer look at this correspondence with a view to shedding light on ways in which the environmental debate could intervene in a layperson's life. ${ }^{57}$

\section{The layperson's voice}

Sören Gunnarsson began his first letter by saying that Palmstierna's articles in Dagens Nyheter had 'meant a lot to me and stimulated my thoughts to focus on the serious problems you are writing about'. Gunnarsson added that the debate on 'contamination and exploitation of the Earth' had intensified in the past year. He expressed growing unease and concern at 'the ruthlessness with which the big industries are ruining future life opportunities'. This short-term thinking was almost as 'disastrous and challenging' as the exploitation of the Third World. Concerned, he turned to Palmstierna for information and guidance. What was being done by those in charge? What were the people who realized that humanity was threatened actually doing? What could a layperson do other than just read the publications of scientists? Were there any pressure groups or petitions? Could not an office be set up to supply the media with information and debate articles? ${ }^{58}$

57 What follows is based on Larsson Heidenblad, 'Överlevnadsdebattörerna'.

58 Letter from Sören Gunnarsson to Hans Palmstierna, undated October 1967, 452/3/2, Hans Palmstierna's personal archive (HP), Swedish Labour Movement's Archives and Library (ARBARK). 
Palmstierna replied to Gunnarsson that the extent of the problems and humanity's short-term covetousness worried him deeply. At the same time, though, he was not disheartened. 'Had I not seen a glimmer of hope, I would not have written the book that was published last week: Plundring-Svält-Förgiftning. It attempts to attack the problems, and, where I see solutions, to suggest some possibilities.' Palmstierna urged Gunnarsson to stand up and work for change. 'The fastest way is probably via the political parties. I am trying to do what I can within the Social Democrat movement, since that party is the most conscientious one where these issues are concerned.' Palmstierna also pointed out that, within the Environmental Advisory Council, an ecology committee had been formed which was intended to function as a lobby group. He concluded by agreeing with Gunnarsson's criticism of the 'selfish desire for profit'. This was what was forcing the destruction of the shared environment. 'There should be no owners', wrote Palmstierna, 'in the sense that a person is allowed to destroy their own property so that third parties or future generations will suffer. There should only be stewards. ${ }^{59}$

Gunnarsson replied on a postcard. He rejoiced that there was 'a book on the way' and hoped it would be a success. 'And that it [will] function better than other "alarm clocks" during this unique autumn. ${ }^{60}$ Shortly afterwards, he sent Palmstierna a newspaper article in which some engineers were interviewed. He said that in itself the article was nothing remarkable, but that it demonstrated the frightening 'cluelessness' displayed by the engineers in the field of environment and energy. ${ }^{61}$

Hans Palmstierna thanked Gunnarsson for 'the naive article'. As he understood it, though, its content was merely a call for 'a more skilfully managed planning of society and more stringent control'. He pointed out that what the engineers had said had been 'filtered through the journalist's feeble intellect' and underlined that bad journalists 'love to end an article with a stupid, preferably derogatory, closing remark'. This is especially true when they have not 'been able to follow along with the conversation'. Possibly 'the discussion by these engineers had made a lot of sense'.

59 Letter from Hans Palmstierna to Sören Gunnarsson, undated October 1967, 452/3/2 (HP ARBARK).

60 Postcard from Sören Gunnarsson to Hans Palmstierna, undated October 1967, 452/3/2 (HP ARBARK).

61 Letter from Sören Gunnarsson to Hans Palmstierna, undated October 1967, 452/3/2 (HP ARBARK). 
The article prompted Palmstierna to develop his thoughts about the conditions of communication. He felt that a key issue was how to spread these crisis insights to a larger number of people. He distanced himself from those who believed that information did not penetrate people's minds unless it was 'as brainless as a comic strip in the Sunday supplement'. This view was an expression of arrogance, he said, and also totally wrong. 'I have observed the opposite. Good information hits home', on condition that it was not presented in an 'obtuse and offensive manner' but in a 'considerate and wise way'. ${ }^{62}$

Palmstierna and Gunnarsson continued to exchange letters during the autumn. Unfortunately, not all of Gunnarsson's letters are preserved. On the basis of Palmstierna's replies, however, it appears that a couple of letters written in November discussed two environmental issues which were current at that time on Sweden's west coast. The first one concerned the city of Gothenburg's wastewater, which threatened the Göta River and the northern parts of the archipelago. Palmstierna argued that a new treatment and sewage system should be built, which would make 'the sewers' materials useful again for forestry and agriculture'.

The second issue concerned the plans to build a sulphate factory in Väröbacka, just north of Varberg. At that time, there were also plans to build a nuclear power plant in that location. On this issue, however, Palmstierna was not so critical of central planning. He explained to Gunnarsson that there were great advantages to industries being densely located: if they were, the surroundings could not be ruined 'without making it impossible for people to work'. This put pressure on decision-makers to develop cleaner processes. Besides, such a concentration made it easier for society to oversee and control the industries. ${ }^{63}$

As well as discussing the political issues of the day, the correspondence mainly focused on how the environmental struggle should be organized and strengthened. In his postcard Gunnarsson said that pressure groups should be set up, a view in which Palmstierna concurred. The latter noted that scientific groupings were being formed, but he felt that a 'lay committee' would be needed too. As a successful example of this, he pointed to the Scientist and Citizen

62 Letter from Hans Palmstierna to Sören Gunnarsson, 6 November 1967, 452/3/2 (HP ARBARK).

63 Letter from Hans Palmstierna to Sören Gunnarsson, 28 November 1967, 452/3/2 (HP ARBARK). 
group in St Louis, which 'from a modest beginning has become very influential'. ${ }^{64}$

Palmstierna admitted that he sometimes 'felt very much alone' and that he 'greatly longed for a fighting group'. However, he said that since the publication of Plundring, svält, förgiftning, it had become apparent that 'there are many friends'. On '[his] list' were both scientists and administrators. They were all socially aware and consciously or unconsciously left wing. Palmstierna singled out the poet and author Svante Foerster as 'a good and combative person'. He added that he had good contacts with the Stockholm-based group called the Young Philosophers. 'We can form a fighting group like that one and also like the American St Louis group. ${ }^{65}$

At the end of the letter, in response to a complaint by Gunnarsson, Palmstierna commented on the publisher's pricing of Plundring, svält, förgiftning. He stressed that he had not written the book in order to make money, and that the high price (approximately 20 euros in today's value) was only due to the publisher's not believing that it would sell particularly well. However, the first edition of the book had already sold out. 'It can only mean that there are many people who think like us - for the most part.' Palmstierna looked ahead with optimism. 'Let us create a popular movement. The time is ripe for it. ${ }^{96}$

The exchange of letters between Sören Gunnarsson and Hans Palmstierna is a single example. It is not possible to draw any far-reaching conclusions about how people in general were affected by, and involved in, the environmental debate on the basis of one such case. Nonetheless, the correspondence does indicate that knowledge was circulating in society. The social distance between a layperson and a scientist was not so great that it could prevent the establishment of a dialogue characterized by trust. Gunnarsson took his own initiatives; he sent articles and asked questions, and Palmstierna answered at length. The exchange of letters shows a genuine desire on both sides to create change and channel

64 Letter from Hans Palmstierna to Sören Gunnarsson, 6 November 1967, 452/3/2 (HP ARBARK).

65 Letter from Hans Palmstierna to Sören Gunnarsson, 28 November 1967, 452/3/2 (HP ARBARK). For a study of the Young Philosophers, see Alexander Ekelund, Kampen om vetenskapen: Politisk och vetenskaplig formering under den svenska vänsterradikaliseringens era (Gothenburg: Daidalos, 2017).

66 Letter from Hans Palmstierna to Sören Gunnarsson, 28 November 1967, 452/3/2 (HP ARBARK). 
commitment. It also indicates how the major perspectives regarding survival were hooked into local issues. In addition, it appears from the letters that both men felt that something had happened recently. A social breakthrough in knowledge had occurred.

A statement of this kind, however, obviously raises many questions. What was the situation like before? What had led to the breakthrough? And did knowledge and expertise really circulate in completely different ways in the autumn of 1967 than, say, in 1955 or 1965? Addressing this type of question requires a different approach than the empirical in-depth study of a limited period. In the next chapter, I will therefore change lenses and take a broader look at the first decades of the postwar period. I will supply an overall characterization of vital lines of development from the late 1940 s to the summer of 1967 , the period in which knowledge about a global environmental crisis was formed. 